\title{
The Risk Hedging Method of Power Market Chaos System Based on The Mode of Futures Trend
}

\author{
Rui $\mathrm{Ma}^{1}$, Fei $\mathrm{Jin}^{2}$,Ningning $\mathrm{Liu}^{3}$,Qian $\mathrm{Hou}^{4}$ \\ 1.2.State Grid Hebei Electric Power Research Institute,Shijiazhuang 050021,China \\ 3.Hebei Elementary Education College of XingTai University,Xingtai,054000,China \\ 4.State Grid Hebei Electric Power Research Institute,Shijiazhuang 050021,China
}

15028125563@163.com

Keyword: The trend of system ;Risk hedging; chaos theory; electricity market

\begin{abstract}
Along with the power market reform in depth, the financial capital market as a breakthrough in the power industry reform and development, accelerate the process of electricity market. This paper introduces a method of power market risk hedge futures trend under the system.To ensure that the market depth of interaction between enterprises in electric power enterprise and industry, provide effective tool for power generation enterprises daily operation with hedging, to avoid the risk of market fluctuations. The coupling relationship between the financial market and the depth of excavation, to guide the generation enterprise more reasonable and efficient energy supply.
\end{abstract}

\section{Introduction}

The focus of the contract coal and coal market, there are obvious differences in the supply of resources, capacity allocation and price level, limiting the role of market mechanism, at the beginning of 2013 key coal contracts canceled, the domestic coal market will be fully liberalized, the state will no longer intervene in coal prices. To determine the transaction price, the two sides have great differences, the lack of domestic coal prices for both reference and scientific authority.

Coal prices is an important basis for the management decision of power generation enterprises, because the price is relatively stable, while the power coal spot market price is scattered, short, is not conducive to the correct decision of enterprises. Thermal coal futures trading in the "open, fair and impartial" trading platform, through a large number of market participants in public auction, fully reflect the factors that affect the market supply and demand, has the characteristics of anticipation, price continuity, openness and authority that contribute to the formation of new electricity pricing system.

\section{Analysis of coal and the fundamentals of seasonal trends}

Overall, although the domestic coal production increased in recent years, the entire industry into the pattern of excess supply, but the supply side still showed seasonal features:.

Analysis of seasonal demand.The domestic coal exports less, mainly in domestic consumption, and consumption of coal demand in the downstream industry accounting point of view, the power industry demand accounted for the largest, reaching about 65\%, building materials, metallurgy, chemical and other industries accounted for about 20\% of total demand, 3.5\%, $1 \%$ and $10 \%$. Therefore, from the demand proportion, electricity and building materials is the main source of coal two downstream industry demand, the proportion reached $85 \%$.

The coal downstream industry segments coal consumption of seasonal statistics can be found, the domestic coal chemical industry and other industries of coal consumption seasonal characteristics is not obvious, which is mainly due to the coal chemical industry and other domestic demand is small , so the demand of seasonal characteristics mainly in electric power, metallurgy and the building materials industry. 
Table 1. Seasonal analysis of coal consumption in the subdivision industry

\begin{tabular}{|c|c|c|c|c|c|c|}
\hline \multirow{2}{*}{ MON } & \multicolumn{2}{|c|}{$\begin{array}{c}\text { Power coal } \\
\text { (Million tons) }\end{array}$} & \multicolumn{2}{c|}{$\begin{array}{c}\text { Meaallutgy coal } \\
\text { (Million tons) }\end{array}$} & \multicolumn{2}{c|}{$\begin{array}{c}\text { Building material coal } \\
\text { (Million tons) }\end{array}$} \\
\cline { 2 - 7 } & $\begin{array}{c}\text { Mean } \\
\text { change }\end{array}$ & $\begin{array}{c}\text { Increased } \\
\text { rate }\end{array}$ & $\begin{array}{c}\text { Mean } \\
\text { change }\end{array}$ & $\begin{array}{c}\text { Increased } \\
\text { rate }\end{array}$ & $\begin{array}{c}\text { Mean } \\
\text { change }\end{array}$ & $\begin{array}{c}\text { Increased } \\
\text { rate }\end{array}$ \\
\hline 1 & -168.75 & $50 \%$ & 66.5 & $100 \%$ & -1610 & $0 \%$ \\
\hline 2 & -2351 & $25 \%$ & -23.75 & $0 \%$ & -661 & $25 \%$ \\
\hline 3 & 2570 & $100 \%$ & 60 & $100 \%$ & 1733 & $100 \%$ \\
\hline 4 & -1159 & $0 \%$ & 10 & $40 \%$ & 699 & $100 \%$ \\
\hline 5 & -299 & $0 \%$ & 14 & $80 \%$ & 413 & $100 \%$ \\
\hline 6 & 216 & $40 \%$ & -13.8 & $40 \%$ & -123 & $80 \%$ \\
\hline 7 & 1290 & $100 \%$ & 3.8 & $80 \%$ & -403 & $0 \%$ \\
\hline 8 & 566 & $100 \%$ & -5.4 & $40 \%$ & -21 & $40 \%$ \\
\hline 9 & -1635 & $0 \%$ & -24.8 & $0 \%$ & 324 & $80 \%$ \\
\hline 10 & 215 & $80 \%$ & 6.8 & $60 \%$ & 304 & $80 \%$ \\
\hline 11 & 671 & $100 \%$ & -45.75 & $25 \%$ & -71 & $25 \%$ \\
\hline 12 & 1229.75 & $100 \%$ & 13 & $50 \%$ & -108 & $25 \%$ \\
\hline
\end{tabular}

Metallurgical Industry: In the first half of the consumption of coal demand tends to increase the performance of strong, 1, 3, 5, 7 in demand amount in the, in February is subject to impact the Spring Festival holiday usually demand reduction, and after entering in September, often showed weak pattern.

Building materials industry: coal consumption performance is more obvious. In the spring and autumn by construction industry opened higher rate driven, consumption demand for coal was shown as in 3-6 months and 9, 10 month appeared to increase; and in November to next February demand is decreasing trend.

Power industry: in the first half of the year in addition to March due to the Spring Festival holiday after the industrial use of electricity demand rise caused by consumption of coal demand rebound outside, other in basic on coal consumption demand is weak. This is mainly due to seasonal effects on the first half of the year, demand for electricity is often low during the year. At the same time, in the domestic addition to accounting for thermal power than around $80 \%$, hydropower accounted for more than 15\%, but in 2-7 month domestic hydropower generation often presents increasing trend, until the beginning of August, domestic hydraulic electricenergy production turn head started to decrease until February of the following year. Therefore, in August as temperatures rise drive increased demand for electricity, thermal power generation also emerge in the increased significantly, the coal demand also showed an increasing trend. And starting in October, with the domestic into the winter storage of coal procurement stage, the power industry to the procurement of power coal demand will rise again, until the end of the year.

Dynamic coal futures technical trend analysis method.According to the seasonal cycle pattern of commodity steam coal, in the first half of the period range, thermal coal in addition to the recovery in demand after the Spring Festival holiday in February, the rest of the time period are in weak consolidation period of decline, but in the hot summer, beginning in August, thermal power output was increased, the thermal coal futures price increases and in October began to January of the next year, has maintained a rising trend.In the situation of clear trend, appropriate technical assistance judgment system can ensure coal futures spread risk and can be the key of return guarantees.Technical System is based on Chaos Theory, the core idea is divided into two parts:

1) mathematical statistics model of coal futures

RSV assignment : ( closing price -the lowest value of the lowest price in 19 days) / (the highest value of the highest price in 19 days-the lowest value of the lowest price in 19 days) * 100

K assignment: the moving average in 9 days[the 1st weights] of RSV

$\mathrm{D}$ assignment: the moving average in 9 days[the 1st weights] of $\mathrm{K}$

J assignment: $3 * \mathrm{~K}-2 * \mathrm{D}$

Output MA3: the simple moving average in 38 days of closing price

Output MA4: the simple moving average in 60 days of closing price 
2) Trend Judgment Rule based on Chaos

First determine all coal futures peak price HHV within a certain time period, and connect them into a line; Determine all coal futures valley price LLV , and connect them into a line.After that,we can get chaotic interval composed of two rolling lines.Steam coal futures price will scroll in this interval before clear trend forms.

Then, use two moving averages on behalf of volatility trend of steam coal price, one for fast line, the other for the slow line.The two lines represent the volatility of coal price in short-term and long-term separately:

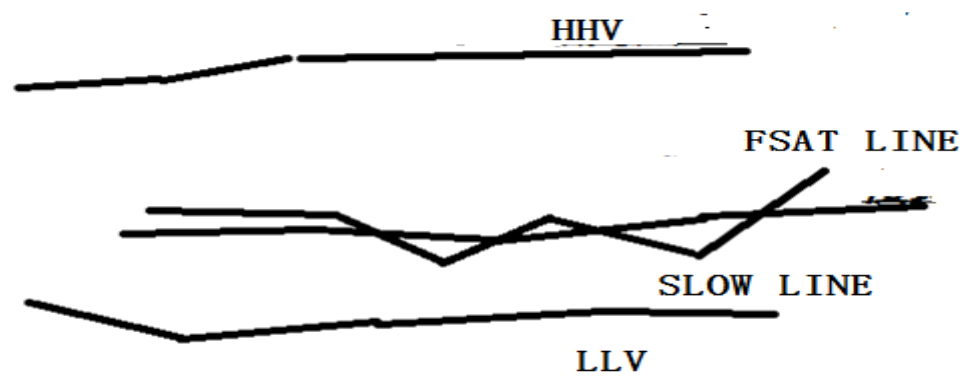

When the two moving averages fluctuate between HHV and LLV, it is can be considered that the price is in the chaotic interval at this time, we should wait ;

When two moving averages clearly break of HHV or LLV and maintain a direction of motion, it is indicated that the trend has generated. We should refer to the seasonal fundamentals mentioned above to take proper technical operations.

The rolling cycle selection of HHV and LLV is critical in the chaotic process. If the selection period is short, it cannot reflect the trend , if the selection period is too long, the reaction will be too slow.After making optimization and improvement to the above algorithm,the criteria as:

Take the medium price of steam coal futures in the same day

TAX:=(the highest price of steam coal in the same day+the lowest price of steam coal in the same day)/2;

Take the weighted moving average price of TAX in the day before

MX:=REF(SMA(TAX,18,1),1);

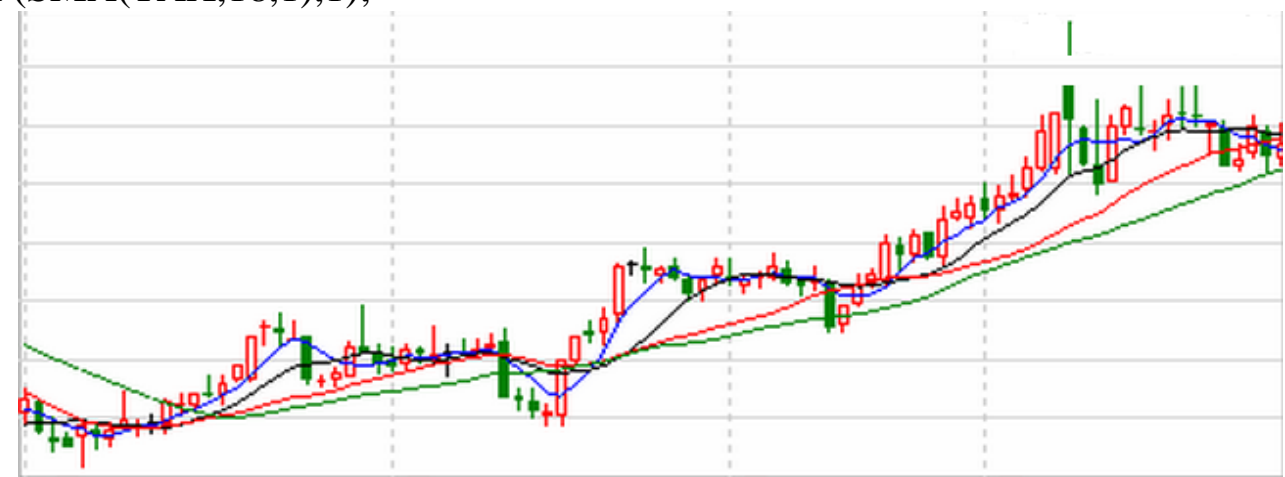

Fig 3.Trend of steam coal futures

The results indicate that chaos system can guide the power company to find the trend of steam coal price in steam coal futures in TC 1509 contract.So futures trading can be carried out to hedge market risk when normal production is in progress.

Specific methods of steam coal futures hedging usd by power companies

First of all to a concept is clear, power generation enterprises are power coal circulation processors. Due to the non synchronization of the power price and the price of the product, the production and operation of the power generation enterprise has certain cost risk.A power plant is expected to purchase 20,000 tons of steam coal in December.Since the electricity price is determined basically, profit targets can be achieved by simply locking procurement cost.Assume profit targets can be achieved when coal price is less than 550 yuan/ton, hedging is bought on August 20th. 


\begin{tabular}{|c|c|c|}
\hline & spot market & futures market \\
\hline August 20th & $\begin{array}{l}\text { Planning to buy } 20 \text { thousand tons } \\
\text { of power coal on December 10th, } \\
510 y u a n / t o n\end{array}$ & $\begin{array}{l}\text { Buying coal } \\
\text { January contract } \\
\text { thousand tons, } \\
580 \text { yuan / ton }\end{array}$ \\
\hline December 10th & $\begin{array}{l}\text { As the price increases, The final } \\
\text { purchase price of } 650 \text { yuan / ton }\end{array}$ & $\begin{array}{l}\text { Futures prices also rose } \\
140 \text { yuan / ton, Sell futures to } \\
720 \text { yuan / ton price }\end{array}$ \\
\hline Profit and loss & $\begin{array}{l}\text { Procurement costs increased by } 2 \\
\text { million } 800 \text { thousand yuan }\end{array}$ & $\begin{array}{l}\text { Futures earnings } 2 \text { million } \\
800 \text { thousand yuan }\end{array}$ \\
\hline Hedging effect & \multicolumn{2}{|c|}{$\begin{array}{l}\text { Futures earnings to make up for the increase in the cost of spot and } \\
\text { prevent the loss of cost fluctuations }\end{array}$} \\
\hline
\end{tabular}

\section{Conclusion}

Presented in this paper based on chaotic trend system futures mode power market risk hedging methods, combined with the fundamentals and technicals, system provides a set of power generation enterprise by means of financial market price discovery, production guidance, insurance to avoid the risk of the system. Power enterprises can also use the physical delivery mechanism of the futures market, to achieve some of the power of coal procurement, production and operation of its stability and continuity play a role in.

On the basis of the further consideration straight power supply companies produce goods and thermal coal spot and futures between linkage relationship, mining to explore the possibility of futures hedging arbitrage model of electric power enterprise risk circumvention mechanism. Reference:

\section{References}

[1] China Futures Industry Association. Compilation of Laws and Regulations of Futures [G].8 edition. Beijing: China financial and Economic Publishing House

[2] Feng Qinyu. Study on the Legal Issues of the Supervision System of the Futures Market of Country [J]. New Finance and Economics: theory version, 2012 